\title{
A COMPARATIVE INQUIRY ON THE MATRIMONIAL DONATIONS IN THE FRENCH AND ROMANIAN LAW \\ C. Codrea
}

\section{Codrin Codrea}

Faculty of Law, Comparative Private Law Department

"Alexandru Ioan Cuza" University of Iași, România

*Correspondence: Codrin Codrea, Faculty of Law, Alexandru Ioan Cuza University of Iași, 11 Carol I St., Iași, România

E-mail: codrin_codrea@yahoo.com

\begin{abstract}
This article analyses in a comparative manner the legal regime of the donations related to the marriage in the French and in the Romanian legal systems. In the French Civil Code there are detailed provisions of the donations made in relation to the marriage, which cover a broader area of donations than the provisions in the Romanian Civil Code which refer only to the donations between spouses.
\end{abstract}

Keywords: donation between spouses, donations matrimoniales, irrevocability of donations

\section{Introduction}

In the French law, the donations between spouses are only one type of donations which are subjected to the legal regime of "donations matrimoniales", which include the donation between spouses also recognized by the Romanian law. Regarding the derogatory regime reserved for matrimonial donations in the French law and for the donations between spouses in the Romanian law, certain differences occurred in the particular legal evolution of each system - one of the differences is that, although the donation between spouses was considered revocable in both legal systems, the French Civil Code does not exclude it anymore from the application of the principle of irrevocability of the donations. This option of the French law can be contrasted to the one in the Romanian law which states, just as the Napoleonic Code did, that the donations between spouses are revocable.

\section{The regime of the donations matrimoniales}

In the French law, the donations between spouses which is explicitly reffered to in the Romanian law, is generally approached in the light of the special nature of the rules which apply to the matrimonial liberalities (liberalités à caractére matrimoniales) $)^{1}$. The donations included in this category, distinctly regulated in the French Civil Code (Chapitre VIII: Des donations faites par contrat de mariage aux époux, et aux enfants à naître du mariage și Chapitre IX: Des dispositions entre époux, soit par contrat de mariage, soit pendant le marriage)) are subjected to a derogatory regime from the general rules which govern the field of donations. ${ }^{2}$

Therefore, in the category of the donations between spouses, in the French law there are included two types of donations - on the one hand the ones made in the

\footnotetext{
${ }^{1}$ Michel Grimaldi, Droit civil. Libéralités. Partages d'ascendants, Litec, Paris, 2000, p. 415, Étienne Riondet, Hervé Sédillot, Transmission du patrimoine, Delmas, Paris, 2003, p. 159

${ }^{2}$ Louis Josserand, Cours de droit civil positif français, Vol. III, Recueil Sirey, Paris, 1930, p. 675
} 
contract of marriage, and on the other, the ones made between spouses during the marriage. ${ }^{3}$ Both types of donations must respect the form conditions of the regular donation, which imply that for their valid conclusion they must be made in an authentic form.

\section{The propter nuptias donations, made in the marriage contract}

The donations made in the marriage contract are considered in the legal French doctrine to be included in the general category of propter nuptias donations which is a notion originating in the Roman law. ${ }^{4}$ In this category there are included those donations made by a third party in the favor of the future spouses, and the donations made between the future spouses. ${ }^{5}$ According to article 1081 of the French Civil Code, these donations are subjected to a derogatory regime form the general rules regarding donations.

Both types of donations have to respect the formal conditions for the valid conclusion of the marriage contract, provided in article 1394 (1) of the French Civil Code. In the French legal doctrine it is considered that the authentic form required for any donation is substituted with the one required for the marriage contract. ${ }^{6} \mathrm{~A}$ derogation from the general regime of donations, article 1087 of the French Civil Code states that the explicit acceptance of the donee is not necessary for the valid conclusion of propter nuptias donations. Also, according to article 1086 of the French Civil Code, the donations made in the marriage contract are not subjected to the irrevocability of donations, therefore a series of contractual provisions are acceptable, such as the ones which constitute conditions of whose realization depend solely on the will of the donor, or provisions according to which the donee accepts to pay all the debt of the donor, even the future debt, or the ones according to which the donor reserves the right to dispose of the donated goods.

Similarly to the article 1030 of the Romanian Civil Code, article 1088 of the French Civil Code states that those donations in favor of the future spouses or of only one of them, under the condition of the conclusion of the marriage, become obsolete in the event of the non-conclusion of the marriage.

\subsection{Donations made in the marriage contract by a third party}

The donations made in the marriage contract by a third party are known in the Legal french doctrine as constitution of dowry (constitutions de dot). ${ }^{7}$ The person who can constitute the dowry can be one of the parents, another ancestor, a collateral relative of one of the spouses or a third party.

In addition to the provisions of articles 1086 and 1088 of the French Civil Code appliable to all propter nuptias donations, the donations made in the marriage contract by a third party cannot be revoked for ingratitude, according to the article 959 of the French Civil Code. The justification for this exception was expressed in the judiciary practice - since such donations do not intend to gratify only the person of the donee, but also his family, it would be unjust for the descendents to suffer consequences of the ingratitude of their gratified parents. ${ }^{8}$ Following the same line of reasoning, the other category of propter nuptias donations, the ones made in the

\footnotetext{
${ }^{3}$ Michel Grimaldi, op. cit., p. 415

${ }^{4}$ Vladimir Hanga, Mircea Dan Bob, Iustiniani Institutiones, Universul Juridic, București, 2009, p. 132

${ }^{5}$ Michel Grimaldi, op. cit., pp. 415-416

${ }^{6}$ Ibidem, p. 434

${ }^{7}$ Ibidem, p. 416

${ }^{8}$ Michel Grimaldi, op. cit., n. (33), p. 420
} 
marriage contract by the future spouses are to be excepted also from the scope of article 959 of the French Civil Code.

According to the article 1440 of the French Civil Code, as a derrogation from the general rules governing donations which state that the donor is responsible for eviction only when it is due to his personal act, the donor of the dowry has to guarantee for eviction in all cases. ${ }^{9}$

The invalidity of the donation made in the marriage contract by a third party can occur in three situations: according to the article 1088 of the French Civil Code, in the event of non-conclusion of the marriage contract, according to the article 1086 of the French Civil Code, in the event of the death of the donee and his descendents and the donation has a provision which allows the donor to dispose of the good, and in the event of the donee's renouncement of the donation with provisions incompatible to the irrevocability of the donations.

\subsection{Donations made by the future spouses in the marriage contract}

Unlike the donation made in the marriage contract by a third party, whose purpose is to provide a certain material security to the future family, the donation made by the future spouses in the matrimonial convention through which the matrimonial regime is also established, is not an external material support for the future family, but a patrimonial arrangement according to the will of the future spouses and an expression of their mutual affection. This type of donation, just like the one made in the marriage contract by a third party, according to the article 1081 of the French Civil Code, is excepted from the compliance to the irrevocability of donations. The practical use of this donation by the future spouses in the marriage contract is rather diminished in the French law, in spite its derrogatory regime from the strict compliance to the irrevocability of the donations. ${ }^{10}$

Regarding these propter nuptias donations, there is an exception from the capacity to make donations, provided in the article 1095 of the French Civil Code. Therefore, the minor, who generally is legally incapable to make donations, neither in his own name nor through a legal guardian, may, however, make donations in favor of his future spouse in the marriage contract, but only if such a donation has the consent and the assitance of those whose consent is also required for the validity of the marriage, according to the principle habilis ad nuptias, habilis ad pacta nuptialis. ${ }^{11}$

As a propter nuptias donation, the donation between the spouses in the marriage contract is governed by the provisions of the article 1088, according to which in the case of non-conclusion of the marriage, the donation is dissolved. ${ }^{12}$

\section{Donations between spouses during the marriage}

In the Romanian law, according to the article 1031 of the Romanian Civil Code which states that all donations between spouses are revocable only during the marriage, it is instituted an exception for the irrevocability of donations, since the donor has the right to revoke anytime during marriage the donation made in the favor of his spouse. This exception was adopted in the article 937 (1) of the Romanian Civil Code of 1865 from the French law, where this rule was in force from the Ancient

\footnotetext{
${ }^{9}$ Mugurel Marius Oprescu, Contractul de donație, Hamangiu, București, 2010, pp. 136-138

${ }^{10}$ Michel Grimaldi, op. cit., pp. 446-447

${ }^{11}$ Francis Lefebvre, Les succesions et les libéralités après la réforme. Loi du 23 juin 2006, Dossier Pratiques, Editions Francis Lefebvre, Levallois, 2006, p. 238

${ }^{12}$ Louis Josserand, op. cit., p. 204
} 
Droit to the Napoleonic Code, which provided this rule in the article 1096 (1) of the Napolenic Code, until the 26 may 2004 Law.

This exception was justified in the French law on the same grounds as it is in the contemporary Romanian law - on the absolute presumption of captivation and suggestion of the donee spouse, who, due to his influence on the other spouse determines him to donate in his favor.

The object of the contract of donation between spouses during marriage can consist only in the donor's own property. In the hypothesis of legal or conventional community of goods regime, as an effect of the donation between spouses, the personal goods of the donor become the personal goods of the donee. ${ }^{13}$ If there were a provision in the contract which stated that the goods are to enter the common ownership of the spouses, the donor spouse would cumulate the quality of a donor and the one of a donee and, therefore, such a provision in the contract cannot be stipulated. ${ }^{14}$

The donor spouse has the right to unilaterally revoke the donation (ad nutum), regardless of the form of the donation - donation made in an authentic form, a simulated or indirect donation or a gift by hand. ${ }^{15}$ This discretionary right can be exercised exclusively by the donor and not by his descendents or creditors, and there can be no provision in the contract which stipulates that the donor renounces his right to revoke the donation. ${ }^{16}$ Thus, the right of the donor spouse is not only a derogation from the irrevocability of the donations, but also from the obligatory force of the contracts, since the donation contract between spouses can be unilaterally revoked by the donor spouse.

Since the donor spouse has an arbitrary right to revoke the donation without the need to justify any cause, the donation between spouses cannot be revoked for failure to execute the charges or for ingratitude. ${ }^{17}$ Only for the revocation of a donation concluded in an authentic form there is required a notarial act, for the revocation of all other forms of donations between spouses an implicit revocation suffices. ${ }^{18}$

In the Romanian law, the simulated donations concluded in order to avoid the revocability of the donations between spouses are invalid. Both the disguised donation, where the true and secret contract is a donation, and the donation by interposition of persons, if they were concluded in order to escape the revocability of the donations between spouses are void, according to the article 1033 (1), (2) of the Romanian Civil Code. Similar provisions regarding the invalidity of the simulated donations concluded to avoid the revocability of the donations between spouses were to be found also in the French law, in the articles 1099 (2) and 1100 of the Napoleonic Code. Similarly to the provisions of the article 1100 of the Napoleonic Code, which, in order to facilitate proof of the donation by interposition of persons instituted an absolute presumption regarding the children from another marriage of the other spouse or regarding persons to whose inheritance the other spouse might acquire, the article 1033 (2) of the Romanian Civil Code presumes as an interposed person any

\footnotetext{
${ }^{13}$ Ion P. Filipescu, Tratat de dreptul familiei, All, București, 1993, p. 73

14 Gabriel Boroi, Liviu Stănciulescu, Instituții de drept civil în reglementarea noului Cod civil, Hamangiu, București, 2012, p. 416

15 Francisc Deak, Tratat de drept civil. Contracte speciale, Ed. IV, (ed.) Mihai Lucian, Romeo Popescu, Universul Juridic, București, 2007, pp. 210-211

${ }^{16}$ Codrin Macovei, Contracte civile, Hamangiu, București, 2006, p. 102

${ }^{17}$ Francisc Deak, op. cit., p. 212

${ }^{18}$ Ioan Popa, Drept civil: moșteniri și liberalități, Universul Juridic, București, 2013, p. 207
} 
relative of the spouse who didn't acquire such a quality from the marriage to the donor, and to whose inheritance the gratified spouse has vocation at the time of the conclusion of the donation contract.

\section{The differences on the revocability of the donations between spouses in the French and Romanian legal systems}

Regarding the revocability of the donations between spouses during marriage, the legal regime governing such donations was similar in the French and in the Romanian law, since in both legal systems it was considered an exception to the special irrevocability of the donation. ${ }^{19}$ Later, in the French law, through a series of legislative changes which were adopted in order to meet the general opinions of the judiciary practice and the legal doctrine, there were adopted different solutions from the one provided in the Romanian Civil Code regarding the legal regime which governs the donations between spouses.

A first modification was adopted in order to clarify the ongoing debate in the judiciary practice and legal doctrine regarding the disguised character of a particular type of donation between spouses - the one of a sum of money for the gratified spouse, so that he can buy with that sum of money a certain good. A part of the judiciary practice considered that, since there is a strong, indivisible connection between the donation of the sum of money and the acquisition of that good, the legal operation is to be qualified as a disguised donation which has as an object the good bought by the gratified spouse. ${ }^{20}$ Such decisions established in the judiciary practice had as a consequence a great uncertainty on the rights acquired by a third party in relation to that good. Therefore, by the Law of $28^{\text {th }}$ of December 1967 the article 1099-1 was inserted in the French Civil Code, which stated in paragraph (1) that the object of the donation is the sum of money and not the purchased good $^{21}$ and according to the article 1099-1 (2) of the French Civil Code, if the donation is to be revoked, the sum of money which is to be returned to the donor has to amount to the actual value of the good.

Later, through the Law no. 305 of $4^{\text {th }}$ of March 2002 regarding parental authority, articles 1099 (2) and 1100 of the French Civil Code which sanctioned with nullity the simulated donations concluded in order to avoid the revocability of the donations between spouses, were repealed. It was appreciated that the absolute presumption which considered as interposed persons the children from outside the marriage of the gratified spouse or his relatives to whose inheritance he has a vocation, was too strict and that it was leading to unjust outcomes. The social reality was revealing the ever growing number of families with children from previous marriages, and in this new social environment the rules regarding the interposition of persons had broader consequences than the ones considered at the adoption of the Napoleonic Code. For example, the sanctioning of the donor spouse with the impossibility to prove that the real gratified is the son from a previous marriage of his spouse, had the consequence of depriving the donor of a way to express his affection and concern regarding the material well being of the child. ${ }^{22}$

The last legislative reform brought by the Law no. 439 of $26^{\text {th }}$ of May 2004 regarding the reform in the field of divorce repealed the article 1096 (1) of the French

\footnotetext{
${ }^{19}$ Jean Maury, Succesions et libéralités, Litec, Paris, 2001, p. 187

${ }^{20}$ Étienne Riondet, Hervé Sédillot, op.cit., p. 170

${ }^{21}$ Pierre Voirin, Gilles Goubeaux, Droit civil. Droit privé notarial. Régimes matrimoniaux. Succesions.

Libéralités, Librairie Générale de Droit et de Jurisprudence, Paris, 2004, p. 325

${ }^{22}$ Mugurel Marius Oprescu, op. cit., pp. 139-141
} 
Civil Code which stated that the donations between spouses are always revocable. In the new text of the article 1096 the donation between spouses are governed by the same rules governing any donation and are subjected to the same causes for revocation as stated in the articles 953-958 of the French Civil Code - failure to execute the charges, ingratitude and birth of child. The justification for this legal option consisted in the fact that a donation whose validity was subjected to the unilateral will of the donor presupposed a high level of uncertainty regarding both the rights of the gratified spouse and the ones of the third parties who might have acquired the donated good from gratified spouse.

The ground for the revocability of donations between spouses was reconsidered - the absolute character of the presumption of captivation and suggestion of the gratified spouse was considered too rigid and thus, in order for a donation between spouses to be dissolved, the corruption of the donor's consent had to be proven. ${ }^{23}$

Since the repeal of the revocability of donations between spouses, the French legal doctrine wondered about the possibility of the spouses to stipulate in the donation contract a provision which allowed the donor to unilaterally revoke the donation, in spite the irrevocability rule which governed the donations between spouses. Such a matter was decided in the French judiciary practice, where the Courts decided that such a contractual provision was valid in some particular situations. The Courts admitted the validity of the Alsatian clause as it was called for its extensive use in the Alsace, in the donations between spouses. This provision stipulated that all donations are to be dissolved in the case of divorce. This jurisprudential solution was recognized by the law, through the reform brought by the Law of 2006 which inserted in the French Civil Code the article 265 (2) which states that all donations between spouses are revoked by law in the case of divorce. ${ }^{24}$ In the Romanian law, the right to revoke the donation can be exercised by the donor spouse only during marriage and in the case of divorce, only before the decision of the dissolution of the marriage becomes definitive and irrevocable. ${ }^{25}$

\section{Conclusions}

Several conclusions can be drawn after this comparative inquiry into the French donations matrimoniales and the correspondent institutions in the Romanian law. First of all, given the opportunity of the adoption of a new Civil Code after the 1865 one, which stated just like this new Civil Code the revocability of the donation between spouses, one possibility of addressing the issues of the uncertainty regarding those donations subjected to the unilateral will of the donor spouse was missed. For the same reasons analyzed above which justified the French legislative reform which repealed the revocability of the donation between spouses, there should have been a similar legal position in the Romanian Civil Code, since the new Romanian Civil Code also introduced different matrimonial regimes. However, not only legal aspects are to be taken into consideration when looking at the revocability of such donations, which affect the rights of donee spouse and the ones of the third parties. Also social and maybe anthropological ones are to be considered, since the donor spouse may gain through significant donations to the other spouse a great amount of control over the latter.

\footnotetext{
${ }^{23}$ Jean-Philippe Levy, Andre Castaldo, Histoire du droit civil, 2eme ed., Dalloz, Paris, 2010, n. 1044, p. 1439

${ }^{24}$ Ioan Popa, op. cit., pp. 205-206

${ }^{25}$ Gabriel Boroi, Liviu Stănciulescu, op. cit., pp. 415-416
} 


\section{Bibliography:}

1. I. Popa, Drept civil: moșteniri și liberalități, Universul Juridic, Bucharest, 2013

2. G. Boroi, L. Stănciulescu, Instituții de drept civil în reglementarea noului Cod civil, Hamangiu, Bucharest, 2012

3. J.-P. Levy, A. Castaldo, Histoire du droit civil, 2eme ed., Dalloz, Paris, 2010

4. M. M. Oprescu, Contractul de donaţie, Hamangiu, Bucharest, 2010

5. V. Hanga, M. D. Bob, Iustiniani Institutiones, Universul Juridic, București, 2009

6. F. Deak, Tratat de drept civil. Contracte speciale, Ed. IV, ed. by M. Lucian, R. Popescu, Universul Juridic, Bucharest, 2007

7. F. Lefebvre, Les succesions et les libéralités après la réforme. Loi du 23 juin 2006, Dossier Pratiques, Editions Francis Lefebvre, Levallois, 2006

8. C. Macovei, Contracte civile, Hamangiu, Bucharest, 2006

9. P. Voirin, G. Goubeaux, Droit civil. Droit privé notarial. Régimes matrimoniaux. Succesions. Libéralités, Librairie Générale de Droit et de Jurisprudence, Paris, 2004

10. É. Riondet, H. Sédillot, Transmission du patrimoine, Delmas, Paris, 2003

11. J. Maury, Succesions et libéralités, Litec, Paris, 2001

12. M. Grimaldi, Droit civil. Libéralités. Partages d'ascendants, Litec, Paris, 2000

13. I. P. Filipescu, Tratat de dreptul familiei, All, Bucharest, 1993

14. L. Josserand, Cours de droit civil positif français, Vol. III, Recueil Sirey, Paris, 1930

This work was supported by the strategic grant POSDRU/159/1.5/S/141699, Project ID 141699, co-financed by the European Social Fund within the Sectorial Operational Program Human Resourses Development 2007-2013 